\title{
Determination of survival and haemocyte response of mud crab Scylla olivacea in vivo challenged with Vibrio
}

\author{
A.F.M. HASANUZZAMAN*, SUSMITA KARMAKER, MARSHIDA KHANOM \\ AND MD. RASHEDUL ISLAM \\ Fisheries and Marine Resource Technology Discipline, Khulna University, Khulna 9208, Bangladesh \\ *Corresponding Author: afmhzzaman@fmrt.ku.ac.bd
}

\begin{abstract}
Vibrio spp. are pathogenic bacteria, and cause shell diseases of Mud crabs. This study was conducted to determine pathogenic load of Vibrio sp. to Mud crab Scylla olivacea by assessing survival and haemocyte cell variation of Mud crabs in vivo challenged with Vibrio sp. Mud crabs collected from local market were firstly acclimatized, and then kept in plastic tanks provided feeding with chopped Tilapia for 9 days. In case of the challenge test, $1 \times 10^{6}, 1 \times 10^{7}$ and $1 \times 10^{9} \mathrm{CFU} \mathrm{ml}{ }^{-1}$ Vibrio sp. were inoculated in the treatment groups $\mathrm{T}_{1}, \mathrm{~T}_{2}, \mathrm{~T}_{3}$, respectively; the control group had no Vibrio inoculums. This study reported that there was a significant difference of mortality rate $(p<0.05)$ between the control and the treatment groups. The control group had no mortality but the treatment groups had 50\% cumulative mortality rate (CMR) on 6 day-post challenge (dpc). The first $100 \%$ CMR was observed in the $\mathrm{T}_{2}$ group, and accordingly, the Vibrio load $>10^{6} \mathrm{CFU} \mathrm{ml}{ }^{-1}$ was found to cause vibriosis in S. olivacea in a short period of time. In this study, haemocyte profile were characterized: the mean total haemocyte count (THC) was $4.71 \pm 0.22 \times 10^{7}, 3.57 \pm 0.61 \times 10^{7}, 4.43 \pm 0.59 \times 10^{7}$ and $5.03 \pm 0.69 \times 10^{7}$ cells ml $^{-1}$ in the $C, T_{1}, T_{2}$ and $T_{3}$ groups, respectively. There was significant difference $(p<0.05)$ between the control and the treatment groups for the THC, and after $6 \mathrm{dpc}$, the THC was found decreased in the treatment groups. There was also variation in the percentage of differential haemocyte count (DHC); larger granular cells were found significantly varied between the control and the treatment groups, pointing out the key role of granular cells in the interaction between $S$. olivacea and Vibrio spp. The present study provides useful information for understanding the immune response of $S$. olivacea to Vibrio infection.
\end{abstract}

Keywords: Mud crab, Scylla olivacea, Haemocyte, Vibrio

\section{Introduction}

Mud crabs (Scylla spp.), the key artisanal coastal fisheries resource in many tropical and subtropical Asian countries, become one of the important export commodities with its high demand in sea food market. Four species of Mud crabs Scylla serrata, $S$. olivacea, $S$. paramamosain and $S$. tranquibarica, are of great commercial importance. $S$. olivacea is the most commonly found Mud crab species in Bangladesh (Rouf et al. 2016). Mud crab fishery and aquaculture supports the livelihood of the fisher-folks in Bangladesh (Azad et al. 2009, Hasanuzzaman et al. 2014). Mud crabs are less susceptible to disease and more resistant to adverse environment conditions, poor water quality and climate change; thus become potential aquaculture species. The present culture system of Mud crab mostly involves fattening of immature (having underdeveloped gonads) and/or underweight ( $<80 \mathrm{~g}$ for female and $<100 \mathrm{~g}$ for male) Mud crab to produce market-size hard-shell crabs, which are exported live. Over the last 6-7 years, soft-shell Mud crab production venture has been practiced, predominantly in the

https://doi.org/10.52168/bjf.2021.33.13 
Kolbari and Munshigonj of the Satkhira district. Accordingly, there has been intensification of Mud crab farming along with high stocking density, and such intensification may result in occurrence of diseases; there have been increasing reports on disease incidence in Mud crabs across the world (Lavilla-Pitogo et al. 2001, He et al. 2003, Lavilla-Pitogo and de la Peña 2004, Poornima et al. 2008, Jithendran et al. 2010). Now-a-days crab fatteners in Bangladesh have also pointed out the disease-associated problems in their farms (pers. commun.). Bacterial diseases are the most ominous concern linked to production loss; among various bacterial diseases, shell disease is most frequently observed. Shell disease, characterized with dark brown or black pigmentation and perforation on shell, is mainly caused by chitinolytic bacteria including Vibrio, Aeromonas.

Like other invertebrates, Mud crabs have innate immunity which is the first line of inducible host defense against bacterial, fungal, and viral pathogens (Hoebe et al. 2004). This innate immune system is composed of cellular and humoral responses, and the cell-mediated defence is principally carried out by haemocytes circulating free amongst all tissues. Crustacean haemocytes have significant role in early nonself recognition, phagocytosis, encapsulation, and elimination of pathogens from the host body (Söderhäll and Smith 1983, Johansson et al. 2000). There are several studies of Mud crabs, including farming practice (Kamal et al. 2003, Salam et al. 2012, Hasanuzzaman et al. 2014, Islam 2015); fattening (Ferdoushi and Xiang-guo 2010); socio-economic status of Mud crab collectors and fatteners in Bangladesh (Molla et al. 2009); but there is no scientific work of Vibrio pathogenicity in $S$. olivacea. Taking into account of such dearth, the present study was developed to assess the immune response of Mud crab ( $S$. olivacea) in vivo challenged with pathogenic bacteria Vibrio sp. To the best of our knowledge, this is the first investigation determining the Vibrio load causing mortality of $S$. olivacea as well as revealing haemocyte-response variation due to in vivo Vibrio challenge.

\section{Materials and Methods}

Mud crab collection and rearing: For conducting this study, 40 healthy, fresh and active Mud crabs of 75-110 g were collected from the depots of Khulna city, and the experiment was conducted in the laboratories of Fisheries and Marine resource Technology Discipline, Khulna University. In order to make crabs prepared for the experiment, crabs were acclimatized in the experimental tanks for 3 days. Then the challenge experiment was conducted in the tanks containing 12 litters water of 10 ppt salinity.

Isolation and perpetuation of Vibrio sp.: Vibrio sp. was isolated from apparently diseased Mud crabs collected from wild sources. The shell, gill, gut and intestinal tract were dissected from the diseased crabs using sterile dissecting instruments, and thereafter pool samples were prepared by mixing these dissected organs from each crab. The pooled sample was homogenized with $1 \mathrm{ml}$ distilled water and kept in a $2 \mathrm{ml}$ Eppendorf tube and stored at $-4{ }^{\circ} \mathrm{C}$ temperature for further use. To obtain isolates, $25 \mathrm{~g}$ of each homogenate was placed in $225 \mathrm{ml}$ of alkaline peptone water (APW; $\mathrm{pH} 8.6$ ), and incubated at $37{ }^{\circ} \mathrm{C}$ for $6-8 \mathrm{hrs}$; a loopful of culture (Enriched APW broth) was then streaked on Thiosulfate-Citrate-Bile Salts-Sucrose (TCBS) agar plate, and incubated at $37{ }^{\circ} \mathrm{C}$ for $24 \mathrm{hrs}$. The plates were checked for the characteristic colony of Vibrio spp., and large (2-3 mm), green with blue centered colony was selected. A pure 
culture of isolated Vibrio sp. was done on TCBS agar plate, and pure culture isolate was kept in Eppendorf tube containing autoclaved distilled water (80\%) and glycerol (20\%) and subsequently stored at $-80{ }^{\circ} \mathrm{C}$. During challenge test, fresh Vibrio was prepared by adding one loopful of stock culture $(\mathrm{V} / \mathrm{V})$ in autoclaved $\mathrm{LB}_{10}$ medium and incubated for $24 \mathrm{hr}$ at $30^{\circ} \mathrm{C}$ on a shaker under constant agitation.

Pathogen challenge test: The challenge test was conducted with selected Vibrio species for 9 days; there were one control group and three treatment groups; each group had replicates. Two crabs were kept in each tank of 12 litters; the control group had no Vibrio inoculums, and the challenge test group had $\mathrm{T}_{1}, \mathrm{~T}_{2}$ and $\mathrm{T}_{3}$ treatments wherein $1 \times 10^{6}, 1 \times 10^{7}$ and $1 \times 10^{9} \mathrm{CFU} \mathrm{ml}^{-1}$ Vibrio were inoculated, respectively. During the challenge period, crabs were fed (at $5 \%$ of body weight) two times daily with chopped Tilapia fish. Crabs were checked two times daily for observing disease and/or infection symptoms as well as mortality. For Haemolymp collection, the Mud crabs were sampled before challenge test and from the control and treatment groups on days post challenge (dpc) when mortality occurred.

Total haemocyte count: Haemolymph $(100 \mu \mathrm{l})$ was collected from the swimming legs using a 1 $\mathrm{ml}$ sterile syringe (25-gauge, $0.45 \mathrm{~mm}$ ) containing $0.9 \mathrm{ml}$ of an anticoagulant solution $(0.114 \mathrm{M}$ trisodium citrate and $0.1 \mathrm{M}$ sodium chloride, at $\mathrm{pH} 7.45$ and with an osmolality of 490 $\mathrm{mOsm} / \mathrm{kg}$ ). The total haemocyte count (THC) was done using a Neubauer haemocytometer chamber (Model: ART1280, China) with a modification of the method described by Bain et al. (2001). A drop of the haemolymph suspension was placed on a haemocytometer to estimate the THC using a trinocular research microscope (Labomed, Model: iVu1500, Lx400, USA).

Differential haemocyte count: Differential haemocyte counts (DHC) were performed following the methods of Celi et al. (2014). Briefly, a drop of haemocytes cell suspension was smeared on a slide to prepare a monolayer and allowed to air dry, and then, the monolayer was fixed with few drops of absolute methanol and inundated for 6 minutes. The haemocyte monolayer was stained with Giemsa solution (1:10 dilution) for 10 minutes and dehydrated with $70 \%$ ethanol for 1 minute and immersed in xylene for 6 minutes (Celi et al. 2014). Then, the cells were observed under the microscope, and haemocytes were differentiated based on morphology and metachromatic staining of cytoplasm, cytoplasmic granules and nuclear chromatin (Hrubec and Smith 2000). Haemocyte differential cells were presented as non-granular haemocyte (NGH), large granular haemocyte $(\mathrm{LGH})$, small granular haemocyte $(\mathrm{SmGH})$, semi granular haemocyte (SGH). At least 200 cells on each slide were counted in random areas, and the DHCs were calculated by using the following equation:

DHC $(\%)=\{$ (Number of different haemocyte cell types) $/$ (Total haemocyte cell counted $)\} \times 100$

Determination of survival: During the challenge test period, the survival of crabs for each experimental group was recorded by the following formula:

$$
\begin{array}{r}
\text { Survival rate }(\%)=\mathrm{Ni}-\mathrm{Nf} /(\mathrm{Ni}) \times 100 \\
\mathrm{Ni}=\text { Initial number of animals } \\
\mathrm{Nf}=\text { Final number of animals. }
\end{array}
$$


Data analysis: All data analysis was carried out using Microsoft office Excel (ver. 2007) and SPSS (version 20). Generalized linear model was used to determine the significant variation of the survival rate, total and differential haemocytes counts among the experimental groups.

\section{Results}

At the beginning of the challenge test period, all Mud crabs were very healthy fresh and active but after 2-3 days, some abnormal symptoms were observed in the treatment groups compared to the control group, and gradually the abnormal symptoms were prominently evident (Table I; Fig.1).

Table I. Physical appearance of Mud crabs in the experiment

\begin{tabular}{lcc}
\hline Characteristics & Control group & Treatment groups \\
\hline Activity & Normal & Slow and sluggard on day 1 \\
Feeding rate & Normal & low feeding on day 2 \\
Body color & Normal & Yellowish color on day 6 \\
Shell condition & Normal & Soft shell \\
Carapace & Normal & Small black spot on the carapace on day 8 \\
Appendages & Normal & Soft and loosen appendages on day 7 \\
Mortality & No occurrence of mortality & Highest mortality on day 8 \\
\hline
\end{tabular}

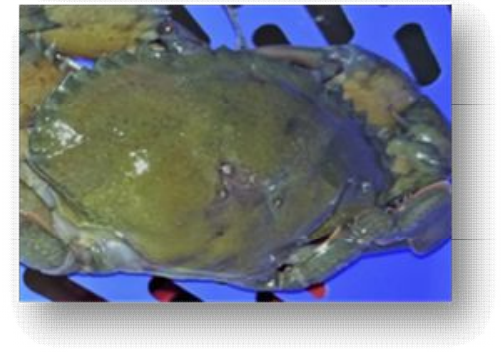

Fig. 1(a). Vibrio infected Mud crab

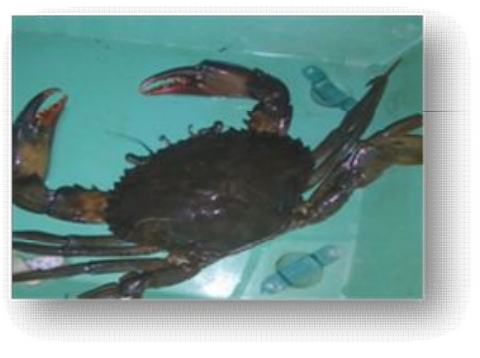

Fig. 1(b). Healthy Mud crab

Mortality of Mud crab: There was no mortality in the control group during the 9 day-challenge test period. The first mortality occurred in the treatment groups $T_{1}$ and $T_{2}$ on 2 dpc but no disease symptoms were found (Table II.). The mortality rate in the treatment groups on $6 \mathrm{dpc}$ and $7 \mathrm{dpc}$ was as same as on $2 \mathrm{dpc}$. The highest mortality was observed on $8 \mathrm{dpc}$. All crabs died in the $\mathrm{T}_{2}$ and $\mathrm{T}_{3}$ groups and the first $50 \%$ cumulative mortality rate (CMR) was found on $6 \mathrm{dpc}$ (Fig.2). 
A.F.M. HASANUZZAMAN et al.

Table II. Mortality (\%) of the experimental Mud crabs

\begin{tabular}{|c|c|c|c|c|c|}
\hline \multirow{2}{*}{$\begin{array}{l}\text { Day after } \\
\text { challenge }\end{array}$} & \multicolumn{4}{|c|}{ Mortality (\%) } & \multirow[t]{2}{*}{ Disease symptoms } \\
\hline & Control $^{\mathrm{a}}$ & Treatment ${ }^{\mathrm{b}}$ & Treatment $^{\mathrm{b}}{ }^{\mathrm{b}}$ & Treatment ${ }^{\mathrm{b}}$ & \\
\hline Day $0^{\mathrm{a}}$ & 0 & 0 & 0 & 0 & \\
\hline Day $1^{a}$ & 0 & 0 & 0 & 0 & \\
\hline Day $2^{\mathrm{b}}$ & 0 & 25 & 25 & 0 & No \\
\hline Day $3^{\mathrm{a}}$ & 0 & 0 & 0 & 0 & \\
\hline Day $4^{\mathrm{a}}$ & 0 & 0 & 0 & 0 & \\
\hline Day $5^{\mathrm{a}}$ & 0 & 0 & 0 & 0 & \\
\hline Day $6^{\mathrm{b}}$ & 0 & 25 & 25 & 0 & White patch on shell \\
\hline Day $7^{\text {b }}$ & 0 & 0 & 25 & 25 & Soft abdomen shell \\
\hline Day $8^{c}$ & 0 & 25 & 25 & 25 & $\begin{array}{c}\text { Small black spot on } \\
\text { the carapace }\end{array}$ \\
\hline Day $9^{c}$ & 0 & 0 & - & 50 & Soft abdomen shell \\
\hline
\end{tabular}

Different superscripts in the same column and in the same raw indicate significant difference $(p<0.05)$.

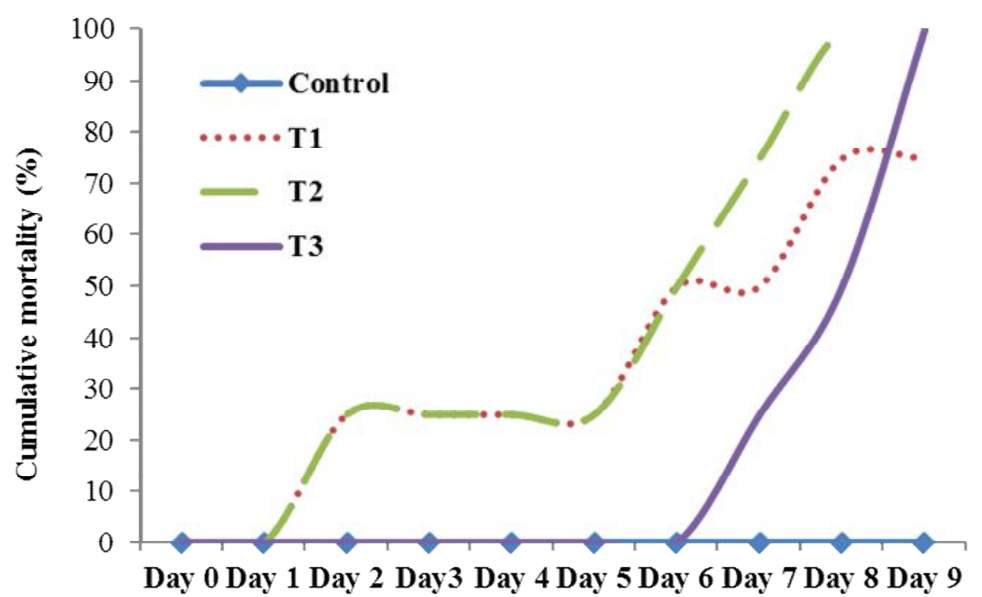

Fig. 2. Cumulative mortality $\%$ of Mud crab challenged with Vibrio sp.

Effect of Vibrio sp. Ioad on Mud crab mortality: The test model effect demonstrated that the Vibrio sp. challenge rendered significant effect on the mortality of Mud crab $(p<0.05)$ (Table II). The faster CMR was detected in the $\mathrm{T}_{2}$ group wherein $1 \times 10^{7} \mathrm{CFU} \mathrm{ml}^{-1}$ Vibrio sp. were inoculated (Fig.2). The exposure of crab to Vibrio sp. with a higher concentration and for long duration might lead to their higher mortality.

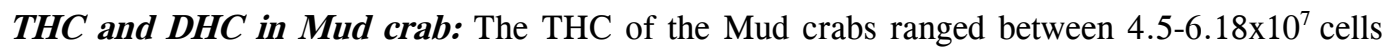
$\mathrm{ml}^{-1}$ before challenge test (Table III). After inoculating Vibrio sp., there was significant difference $(p<0.05)$ of THC between the control and the treatment groups (Fig.3); the highest $\mathrm{THC}$ was found in the $\mathrm{T}_{3}$ group till $7 \mathrm{dpc}$. 
SURVIVAL \& HAEMOCYTE RESPONSE OF S. OLIVACEA IN VIVO CHALLENGED WITH VIBRIO

Table III. THC (cell/ml) and DHC (\%) in Mud crabs before challenge test

\begin{tabular}{|c|c|c|c|c|c|}
\hline \multirow[t]{2}{*}{ Tank } & \multirow{2}{*}{$\begin{array}{l}\text { THC cells } \\
\mathrm{ml}^{-1}\end{array}$} & \multicolumn{3}{|c|}{ DHC \% } & \multirow[b]{2}{*}{ Non granular } \\
\hline & & Large granular & Semi granular & Small granular & \\
\hline $\mathrm{T} 1$ & $4.5 \times 10^{7}$ & $46.33 \pm 3.64$ & $18.33 \pm 3.04$ & $19.66 \pm 1.79$ & $18.04 \pm 2.30$ \\
\hline $\mathrm{T} 2$ & $6.03 \times 10^{7}$ & $42.33 \pm 2.16$ & $20.02 \pm 6.89$ & $17.33 \pm 3.35$ & $21.33 \pm 4.28$ \\
\hline $\mathrm{T} 3$ & $6.18 \times 10^{7}$ & $45.01 \pm 3.64$ & $15.33 \pm 2.39$ & $21.07 \pm 3.76$ & $19.66 \pm 3.34$ \\
\hline Control & $4.94 \times 10^{7}$ & $57.66 \pm 1.79$ & $15.06 \pm 3.24$ & $19.03 \pm 3.74$ & $10.66 \pm 3.64$ \\
\hline
\end{tabular}

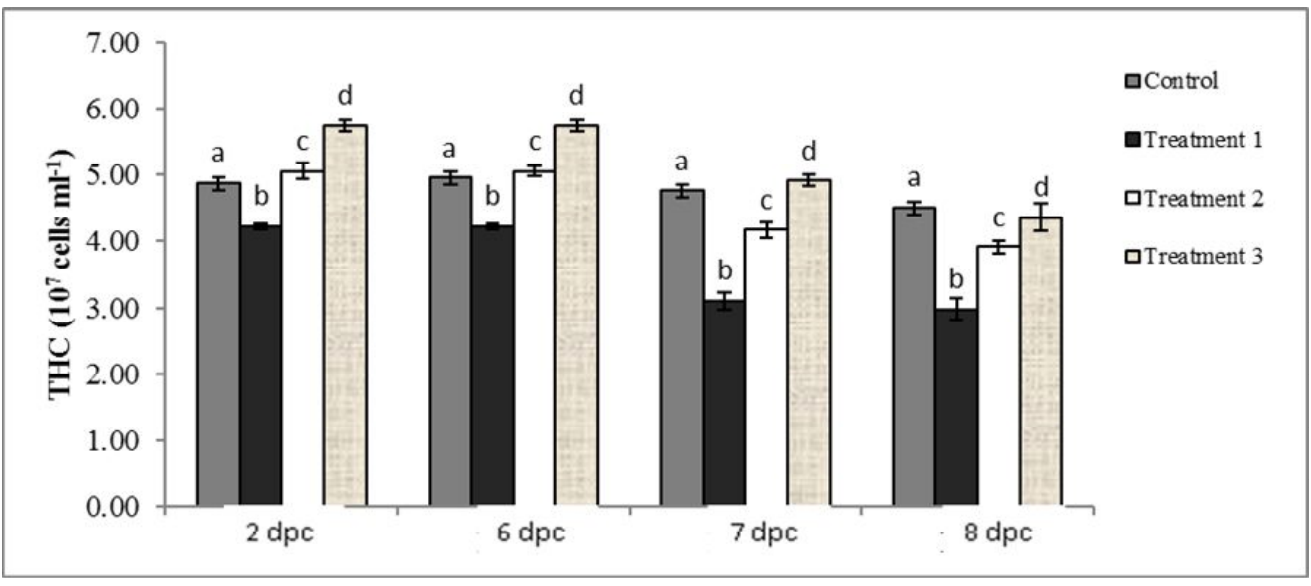

Fig. 3. THC (cells/ml) of Mud crabs after challenge test.

Differential haemocyte count (DHC) during challenge test: The DHC analysis reveals that the highest LG count $(16.46 \%)$ was found in $\mathrm{T}_{3}$ on $6 \mathrm{dpc}$ and the lowest LG count $(7.23 \%)$ was found in $\mathrm{T}_{2}$ on $8 \mathrm{dpc}$ (Table IV). There was no significant difference $(p>0.05)$ found within the control group for LG cells during the experiment period but the LG counts were significantly different $(p<0.05)$ among the experimental groups. In case of SG cells, the highest count (39.06\%) was found in the $\mathrm{T}_{2}$ on $2 \mathrm{dpc}$ and the lowest count (21.96\%) in the $\mathrm{T}_{1}$ on $8 \mathrm{dpc}$. There was significant difference $(p<0.05)$ between the control group and the treatment groups, but no significant difference between $\mathrm{T}_{2}$ and $\mathrm{T}_{3}$. The highest SmG count was in the $\mathrm{T}_{1}(47.62 \%)$, and the lowest $\mathrm{SmG}$ cells in the $\mathrm{T}_{2}$ group $(29.89 \%)$ on $8 \mathrm{dpc}$, and significant difference $(p<0.05)$ between the control and the treatment groups was observed. In case of NG cells, no significant difference was found between the control group and the treatment groups. The lowest NGH count $(9.84 \%)$ was found in the control group on $7 \mathrm{dpc}$, and the highest (26.31\%) on $6 \mathrm{dpc}$ in the $\mathrm{T}_{1}$ group. 
A.F.M. HASANUZZAMAN et al.

Table IV. DHC \% (Mean \pm SD) of Mud crabs during the challenge period

\begin{tabular}{lccccc}
\hline Groups & $\begin{array}{c}\text { Differential } \\
\text { haemocyte cell }\end{array}$ & $2 \mathrm{dpc}$ & $6 \mathrm{dpc}$ & $7 \mathrm{dpc}$ & $8 \mathrm{dpc}$ \\
\cline { 3 - 6 } Control & & & & & \\
& LG & $11.61 \pm 4.77$ & $12.57 \pm 4.21$ & $13.02 \pm 2.65$ & $12.01 \pm 2.08$ \\
& SG & $31.67 \pm 4.55$ & $32.89 \pm 2.82$ & $37.49 \pm 1.71$ & $38.18 \pm 2.94$ \\
& SmG & $40.63 \pm 4.01$ & $42.21 \pm 4.89$ & $40.01 \pm 1.71$ & $35.92 \pm 5.88$ \\
Treatment 1 & NG & $16.09 \pm 3.86$ & $12.36 \pm 2.98$ & $9.84 \pm 6.24$ & $13.72 \pm 4.19$ \\
& LG & $10.94 \pm 2.22$ & $9.10 \pm 2.65$ & $9.66 \pm 2.50$ & $8.56 \pm 3.10$ \\
& SG & $28.08 \pm 4.57$ & $24.53 \pm 4.40$ & $22.61 \pm 3.11$ & $21.96 \pm .96$ \\
Treatment 2 & SmG & $42.16 \pm 3.39$ & $39.62 \pm 3.10$ & $46.98 \pm 2.82$ & $47.62 \pm 5.12$ \\
& NG & $18.79 \pm 3.39$ & $26.31 \pm 3.56$ & $19.74 \pm 4.51$ & $21.52 \pm 4.27$ \\
& LG & $12.53 \pm 2.99$ & $14.34 \pm 3.51$ & $11.94 \pm 2.58$ & $7.23 \pm 1.83$ \\
Treatment 3 & SG & $39.06 \pm 3.30$ & $34.63 \pm 4.27$ & $33.89 \pm 4.35$ & $29.24 \pm 1.71$ \\
& SmG & $34.37 \pm 5.06$ & $32.24 \pm 2.70$ & $29.89 \pm 2.08$ & $25.01 \pm 4.35$ \\
& NG & $16.01 \pm 4.20$ & $18.78 \pm 3.30$ & $24.69 \pm 1.50$ & $25.06 \pm 2.52$ \\
& LG & $15.32 \pm 4.03$ & $16.46 \pm 4.64$ & $12.03 \pm 5.08$ & $10.94 \pm 3.30$ \\
& SG & $33.23 \pm 4.79$ & $31.63 \pm 4.79$ & $30.69 \pm 2.22$ & $29.13 \pm 4.04$ \\
& SmG & $37.51 \pm 4.79$ & $40.12 \pm 3.30$ & $37.31 \pm 2.49$ & $39.81 \pm 3.30$ \\
& NG & $13.97 \pm 5.45$ & $11.54 \pm 4.11$ & $20.01 \pm 2.22$ & $20.13 \pm 4.19$ \\
\hline
\end{tabular}

\section{Discussion}

Vibrio spp. is one of the main pathogens to cause high levels of mortality in the culture industry of Mud crabs. Lavilla-Pitogo et al. (2001) reported shell disease in the Mud crabs after being held in tanks for three months, and speculated Vibrio spp. as the causative agent. The present study was attempted to evaluate the immune competence of $S$. olivacea against pathogenic bacteria Vibrio. During 9 day-long challenge test period, all crabs of the control group were very healthy and alive; no disease symptoms or mortality was found. But in the Mud crabs of the treatment groups, some abnormal symptoms (brown or light red patch on shell, soft abdomen shell and small black spot on carapace) were observed from $2 \mathrm{dpc}$ and gradually the abnormal symptoms were prominently evident and lastly mortality occurred, which pointing out the pathogenicity of Vibrio sp. Such symptoms are characteristic features of shell diseased crabs; there are discolored patches on the carapace initially appeared on the carapace, soft exoskeleton and calcified tissue underneath exoskeleton of Mud crabs challenged with Vibrio (Lavilla-Pitogo et al. 2001).

The present study determined the pathogenic load of green Vibrio sp.; the treatment group $\mathrm{T}_{1}$ with $1 \times 10^{6} \mathrm{CFU} \mathrm{ml}{ }^{-1}$ Vibrio inoculum had $75 \%$ mortality but no severe disease symptoms were observed. On the other hand, $1 \times 10^{7}$ and $1 \times 10^{9} \mathrm{CFU} \mathrm{ml}{ }^{-1}$ Vibrio inoculation caused $100 \%$ mortality of Mud crabs with diseased symptoms. Such pathologic variation was likely associated with Vibrio load and exposure duration. According to Srimeetian et al. (2017), 100\% cumulative mortality was found on 1 and 2 day after challenging the healthy Mud crabs with $10^{8}-10^{10}$ and $10^{7} \mathrm{CFU} \mathrm{ml}{ }^{-1} \mathrm{~V}$. parahaemolyticus. During 30 day-challenge period, the cumulative mortality was $22.22 \%$ with $10^{6} \mathrm{CFU} \mathrm{ml}{ }^{-1}$ but no cumulative mortality was detected with $10^{5}-10^{1}$

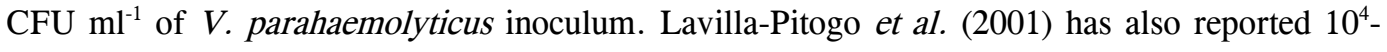


$10^{7} \mathrm{CFU} \mathrm{g}{ }^{-1}$ Vibrio count in severely diseased exoskeleton of Mud crab broodstock held in the tank for 3 months. Accordingly, the present study pointed out that the green Vibrio load greater than $10^{5} \mathrm{CFU} \mathrm{ml}{ }^{-1}$ might cause mortality of $S$. olivacea when exposed for long period of time.

In host-pathogen interaction studies, the profile of haemocytes is widely used to evaluate the health status of the target species. Haemocytes play very crucial role in the defence system of crustaceans against microbial pathogens: phagocytosis, haemocyte clotting, hardening of exoskeleton, healing of cuticle damage, encapsulation (Johansson and Soderhall 1989, Noga et al. 2000). The present study estimated THC in the range of $2.98-5.75 \times 10^{7}$ cells $\mathrm{ml}^{-1}$, which is almost similar to the mean THC $\left(2.86 \times 10^{7}\right.$ cells $\left.\mathrm{ml}^{-1}\right)$ of $S$. serrata (Kumar et al. 2013). The haemocytic response of $S$. olivacea to Vibrio infection was characterized; the THCs of the healthy crabs were not significantly varied in the healthy crabs but there was varied trend of the THCs in the Vibrio challenged crabs along the challenge period. The higher THC of the Mud crabs in the treatment groups might be associated with initial stage of vibrosis, when the haemocytes are likely increased in the circulating system and differentiated variedly to provide defence against invading pathogens. On the other hand, the reduction of the THC on 7 and $8 \mathrm{dpc}$ was an indicative of immunological suppression in response to critical stage of vibriosis characterized with higher mortality of Mud crabs in the present investigation. It is of note that compared to the control group, the THC in the $\mathrm{T}_{1}$ group was found lower to which Vibrio load was likely linked since the haemocyte count can be varied with infection type and environmental stress (Persson et al. 1987, Smith and Jhonston 1992); however, this fact has to be elucidated through further prudent studies.

The present study also revealed that the Vibrio infection caused variation in the haemocyte sub-type count of $S$. olivacea, as reported in crustaceans exposed to pathogens by Sequeira et al. (1996) and Zhou et al. (2018). In comparison with the control group, the LG, SG and SmG morphotypes of the haemocytes varied significantly. There was no distinct trend in granulocytes of Mud crabs in the control group while the LG and SG counts of the treatment groups follow a pattern; like the THC in the $\mathrm{T}_{2}$ and $\mathrm{T}_{3}$ groups, there was increasing number of LG cells till 6 dpc, and thereafter the counts were reduced. Regarding semi-granular cells, there is decreasing number of these cells along the challenge period. In the interaction between $S$. olivacea and Vibrio sp., such observations pointed out the role of granular cells which are actively involved in phagocytosis (Noga et al. 2000, Zhang et al. 2013) and in hydrolytic, oxidative, phenoloxidase enzyme activities as well as superoxide anion production (Matozzo and Marin 2016). However, the immune function of haemocyte sub-population of $S$. olivacea in response to vibriosis is to be explored explicitly through further enzymatic and gene expression studies. In conclusion, this study demonstrated that the Vibrio infection caused mortality of $S$. olivacea, and the load greater than $10^{6} \mathrm{CFU} \mathrm{ml}^{-1}$ was found to cause disease symptoms in $S$. olivacea under experimental condition. There was change in THC and DHC between the control and the treatment groups, and such variation in THC and DHC suggests the role of $S$. olivacea haemocytes against vibriosis.

Acknowledgements: The authors would like to acknowledge the financial support of World Bank, International Fund for Agricultural Development IFAD and Government of Bangladesh and the supervision of PIU-BARC, NATP-2 project to carry out this research work. S. Karmaker is also grateful to NST fellowship during her MS program. 


\section{A.F.M. HASANUZZAMAN et al.}

\section{Literature Cited}

Azad, A.K., K.R. Jensen and C.K. Lin, 2009. Coastal aquaculture development in Bangladesh: unsustainable and sustainable experiences. Environ. Manage., 44(4): 800-809.

Bain, B.J., I. Bates, S.M. Lewis, J. Dacie, 2001. Practical Haematology. Health Sciences Division. 652 p.

Celi, M., F. Filiciotto, M. Vazzana, V. Arizza, V. Maccarrone, M. Ceraulo and G. Buscaino, 2014. Shipping noise affecting immune responses of European spiny lobster (Palinurus elephas). Can. J. Zool., 93(2): 113-121.

Ferdoushi, Z. and Z. Xiang-guo, 2010. Mud crab (Scylla serrata) fattening in Bangladesh: present status and future prospects. Recent Adv. Fish. Bangladesh, 1: 191-202.

Hasanuzzaman, A.F.M., S.T. Arafat and K.A. Huq, 2014. Mud Crab (Scylla spp.) Aquaculture in the South-West Sundarbans Region of Bangladesh. Iraqi J. Aquac., 11(1): 57-83.

He, Q., S. Wang, C. You and Y. Li, 2003. Immune response of Mud crab, Scylla paramamosain, to bacterial lipopolysaccharide. J. World Aquac. Soc., 47(6): 843-853.

Hoebe, K., E. Janssen and B. Beutler, 2004. The interface between innate and adaptive immunity. Nat. Immunol., 5(10): 971.

Hrubec, K. and V. J. Smith, 2000. Separation of the haemocyte populations of Carcinus maenas and other marine decapods, and prophenoloxidase distribution. Dev. Comp. Immunol., 7(2): 229-239.

Islam, M. 2015. Status of Mud crab aquaculture in Bangladesh. In Proceedings of the International Seminar-Workshop on Mud Crab Aquaculture and Fisheries Management, 10-12 April 2013, Tamil $\mathrm{Nadu}$, India (pp. 1-6). Rajiv Gandhi Centre for Aquaculture (MPEDA).

Jithendran, K.P., M. Poornima, C.P. Balasubramanian and S. Kulasekarapandian, 2010. Diseases of Mud crabs (Scylla spp.): an overview. Indian J. Fish., 57(3): 55-63.

Johansson, M.W., P. Keyser, K. Sritunyalucksana and K. Söderhäll, 2000. Crustacean haemocytes and haematopoiesis. Aquaculture, 191(1-3): 45-52.

Johansson, V.S. and K. Söderhäll, 1989. Separation of the haemocyte populations of Carcinus maenas and other marine decapods, and prophenoloxidase distribution. Dev. Comp. Immunol., 7(2): 229-239.

Kamal, D., M.S. Tapadar and M.F. Uddin, 2003. Production, marketing and transportation of Mud crab (Scylla olivacea) from the Southwestern region of Bangladesh. The Sundarbans, the Largest Mangrove Forest on the Earth: A World Heritage Site (ed. by MG Murtaza), 123-143.

Kumar, B., A. Deepika, M. Arumugam, P. Mullainadhan, M. Makesh, Gayatri Tripathi, C.S. Purushothaman, and K. V. Rajendran, 2013. Microscopic and cytochemical characterisation of haemocytes of the mud crab Scylla serrata (Forskål, 1775) (Decapoda, Portunidae) . Crustaceana, 86(10):1234-1249.

Lavilla-Pitogo, C.R. and L.D. de la Peña, 2004. Diseases in farmed Mud crabs Scylla spp.: Diagnosis, prevention, and control. Aquaculture Department, Southeast Asian Fisheries Development Center, $187 \mathrm{p}$.

Lavilla-Pitogo, C.R., H.S. Marcial, S.A.G. Pedrajas, E.T. Quinitio and O.M. Millamena, 2001. Problems associated with tank-held Mud crab (Scylla spp.) broodstock. Asian Fish. Sci., 14(2): 217-224.

Matozzo, V. and M.G. Marin, 2016. The role of haemocytes from the crab Carcinus aestuarii (Crustacea, Decapoda) in immune responses: A first survey. Fish Shellfish Immunol., 28(4):534-541.

Molla, M.A.G., M.R. Islam, S. Islam and M.A. Salam, 2009. Socio-economic status of crab collectors and fatteners in the southwest region of Bangladesh. J. Bangladesh Agric. Univ., 7(2): 411-419.

Noga, E.J., R. Smolowitz and L.H. Khoo, 2000. Pathology of Shell disease in the blue crab, Callinectes sapidus, Rathbun (Decapoda: Portunidae). J. Fish Dis., 23: 389-399.

Persson, M., L. Cerenius and K. Soderhall, 1987.The influence of the freshwater crayfish Pacifastacus leniusculus Dana, to the parasitic fungus Aphanomycesastaci. J. Fish Dis. 10: 471-477.

Poornima, M., M. Kathirvel, S. Kulasekharapandian, T.C. Santiago, N. Kalaimani, K.P. Jithendran, S.V. Alavandi, and R. Saraswathi, 2008. Occurrence of white spot syndrome virus in cultured mud crab Scylla tranquebarica. In: Compendium of International Conference on 'Emerging infectious diseases 
of animals and biotechnological applications' , 28-29 July, 2008, Tamil Nadu Veterinary and Animal Sciences University, Chennai, India. 94 p.

Rouf, M.A., S.I. M. Shahriar, M.G. Sarower, and M.N. Ahsan, 2016. Taxonomic clarification of Mud crab species of genus Scylla (Brachyura: Portunidae) available in the coastal regions of Bangladesh. Asian Fish. Sci., 29:124-136.

Salam, M.A., S.M.M. Islam, J. Gan and L. Ross, 2012. Crab culture potential in southwestern Bangladesh: alternative to shrimp culture for climate change adaption. Int. Res. J. Appl. Life Sci., 1(4): 15-31.

Sequeira, T., D. Tavares and M. Arala-Chaves, 1996. Evidence for circulating hemocyte proliferation in the shrimp Penaeus japonicus. Dev. Comp. Immunol. 20: 97-104.

Smith, V.J. and P.A. Johnston, 1992. Differential haemotoxic effect of PCB congeners in the common shrimp, Crangon crangon. Comp. Biochem. Physiol., Part C: Pharmacol. Toxicol. Endocrinol. 101: 641-649.

Söderhäll, K. and V.J. Smith, 1983. Separation of the haemocyte populations of Carcinus maenas and other marine decapods, and prophenoloxidase distribution. Dev. Comp. Immunol, 7(2): 229-239.

Srimeetian, P., J. Suwanmala and S. Tunkijjanukij, 2017. Virulence of Vibrio parahaemolyticus in Mud Crab (Scylla spp.). J. Mahanakorn Vet. Med., 12(1): 19-27.

Zhang, Z., S. Li, C. Xie, L. Zhou, C. Li, W. Liu, and X. Wen, 2013. Innate immune response and gene expression of Scylla paramamosain under Vibrio parahaemolyticus infection. Aquac. Res., 46(2): $462-$ 471.

Zhou Y. L., W.B. Gu, D.D. Tu, Q.H. Zhu, Y.Y. Chen and M.A. Shu, 2018. Hemocytes of the Mud crab Scylla paramamosain: Cytometric, morphological characterization and involvement in immune responses. Fish Shellfish Immunol., 72: 459-469.

(Manuscript received: 24 May 2021) 